\title{
THE HISTORICAL INFLUENCE OF LANDSCAPE, ECOLOGY AND CLIMATE ON DANISH LOW-RISE RESIDENTIAL ARCHITECTURE
}

\author{
MIKKEL POULSEN \& MICHAEL LAURING \\ Department of Architecture, Design and Media Technology, Aalborg University, Denmark.
}

\begin{abstract}
Architecture has historically had to respond to landscape, ecology and climate. The paper investigates how this relationship has developed in Danish architecture, and how architecture of the future may develop during climate change. Through literature studies on the subject of Danish low-rise residential architecture and on climatic adaptation, it has been examined how late vernacular, modernistic, regional, modern and ecological/sustainable residences have responded to landscape and climate. Vernacular architectural designs were based on inter-generational knowledge of how to design according to the landscape and environment with materials locally available within communities. The connections with the landscape were intrinsic but were wholly anthropocentric by necessity. The 1920s' introduction of Modernism and the International Style reduced the importance of local landscape and climate. Danish architects of the era started to incorporate architectural elements and colors from foreign climates, at the expense of lessons from the vernacular. The regional modernism in Denmark sought to reconcile a regional architecture with the functionality of modernism. This architecture was better suited to the local climate and connected with local materiality. The 1960s saw a demographic and housing boom, the consequence of which was hastily built 'cookie-cutter' housing and concrete apartment blocks that still dominate the housing stock. The oil crisis of the 1970s hit Denmark hard, enforcing energy savings on architecture, which over time developed to become reliant on passive solar strategies and thermal mass. The current Danish sustainable architecture has a primary focus on minimizing greenhouse gas emissions; the control of the indoor climate diminishes the connection to the exterior environment. Danish architecture must merge the vernacular understanding of climate and landscape with the mitigating properties of sustainable architecture. An embedding in the landscape and climate will reduce the impacts of climate change.

Keywords: architectural history, bioclimatic design, climate adaptation, climate change, vernacular design
\end{abstract}

\section{INTRODUCTION}

Climate, landscape and ecology are natural conditions of architecture, but their influence have waxed and waned over time. In this age of climate change and its mitigation, these three factors are important in architectural designs.

This paper describes how the development of low-rise residential architecture in Denmark has depended on architectural relationships to climate, landscape and ecology. There will be a short chronological description of each architectural period followed by a discussion of the architectural relationship with the natural conditions. A summary of the characteristics will outline the direction of the developments in relationship with nature.

The goal of the paper is to understand how the development in residential architecture has laid the foundation for the current relationship with the natural conditions and which architectural elements may improve the resilience of new, sustainable housing and architecture.

\subsection{Background}

Currently, most scientific evidence points to a global shift in climate in the near future. This is the result of increasing greenhouse gases in the atmosphere [1]. 
The shifts will correspond to the local climate zone, with similar climates facing similar changes. Buildings are of course subject to these changes, and in particular architecture designed narrowly for the environment and landscape in which it is currently situated can be negatively affected.

In Denmark, the effects are apparent through destructive floods in cities and summer overheating in houses otherwise suited for the climate.

Adapting the architecture to climate changes is therefore paramount in all future buildings.

\subsection{The Danish landscape}

The Danish landscape is a product of the ice age, pushed up from the seafloor by glacial forces. There are no rock formations or mountain ranges. Most of the country consists of a coastal lowland archipelago. According to the Köppen classifications, the Danish climate is defined as a cold oceanic climate [2].

The Danish landscape is characterized by low rolling hills, the highest point being $171 \mathrm{~m}$ above sea level. The forests that covered the land in ancient times are now converted into fields and meadows, covering over $70 \%$ of the land with few protected areas remaining. This has led to a landscape susceptible to the strong winds in this region. Variations in soil and local climate can create surprisingly unique landscapes. Coastal erosion plays a major part in the shaping of the landscape as well, with the western coast eroded by the sea, while the eastern coast grows. Denmark lies between the North Sea and the Baltic Sea, which causes large swells when bodies of water move towards one another. The Danish coast is littered with inlets, of which some have been dammed to provide farmland or city expansions. These areas are naturally vulnerable to flooding, the lowest of these reaching $7.5 \mathrm{~m}$ below sea level.

Denmark has a mutable landscape, subject to rapid change by natural forces. Extraordinary weather events usually leave some kind of change in the landscape. The last decades of extraordinary weather have thus changed the dynamics of the Danish landscape extensively. For instance, strong winter storms have been afflicting Denmark since the turn of the millennium, speeding up coastal erosion and bringing swells to vulnerable coastal areas [3].

\section{METHODS}

\subsection{Literature study}

Literature studies have been the backbone in understanding the development of Danish architecture, the brunt of the literature used in the studies being books on Danish housing architecture.

Several works discuss the Danish residential architecture in a historical context, and from there connections to the theme of the paper have been made. Since a large part of the development in Danish residential architecture depends on policies, it has been important to understand the political forces that have acted on the residential sector primarily through the 20th century.

\subsection{Case studies}

The paper uses relevant case studies to support the findings of the literature study and to exemplify the relationship to climate, landscape and ecology in residential architecture of the 
described periods in Danish history, but with a primary focus on residential architecture from the 20th century and onwards. Descriptions of materials, constructions, architectural form and their relationship with external natural factors are derived from the cases.

\section{THE LONGHOUSE AND WINGED FARM}

Danish vernacular architecture took shape in the Stone Age settlements. Buildings of the age were rough rectangular longhouses originally constructed with wooden posts dug into the ground. The houses in the following Bronze Age followed a similar development. The climate in the Bronze and early Iron Age was warm and mild.

These ancient houses were all longhouses, in most cases lying on an axis from east to west. Thus, the long façade faced the south and the sun; the western hipped gable faced towards the predominating western winds, while the hipped eastern gable turned towards the cold eastern winds typically blowing through wintertime (Fig. 1). Following a climatic shift in the Iron Age, animals were placed in the eastern end of the longhouse, bringing warmth to the human section when the winds were cold [4].

The longhouses were prominent in the Danish countryside, the architecture being one that could be extended, especially in length and to a lesser degree orthogonally, as needed. The houses could develop with the needs of the inhabitants.

During the late Middle Ages, the longhouses developed into the three or four winged farms, providing a wind-sheltered outdoor space in the increasingly deforested Danish landscape (Fig. 2). The residential wing would still run from east to west with the façade facing south.

In the Middle Ages, the building practice of wooden posts dug into the ground was restricted due to the large consumption of timber. Instead, the wooden house stood on a stone foundation lifting it off the ground. As the Danish forests steadily diminished due to the need for building materials, fences, boats and not least firewood, building practice turned into halftimbering with the panels between the posts filled with clay, later on with burnt brick stones.

Danish farmhouses were originally gathered in small villages, with the farms typically organized around a central, common area. During the large land reforms in the late 18th century, many villages split up, and farms moved into the open land closer to the farmers' individual fields and meadows. Timber constructions were reused in this process and the farmhouses placed halfway down the hill; never on top of the hill where strong winds would blow and never at the bottom where moisture and water would gather [5,6].

The vernacular architecture developed through inter-generational and communal trial and error. It was normal for everyone in the community to help in the construction of new houses, and therefore everyone understood the construction methods and materiality of the houses. The houses created thus had a uniform style but with a wealth of variations decided by the needs and wants of the individual owners.

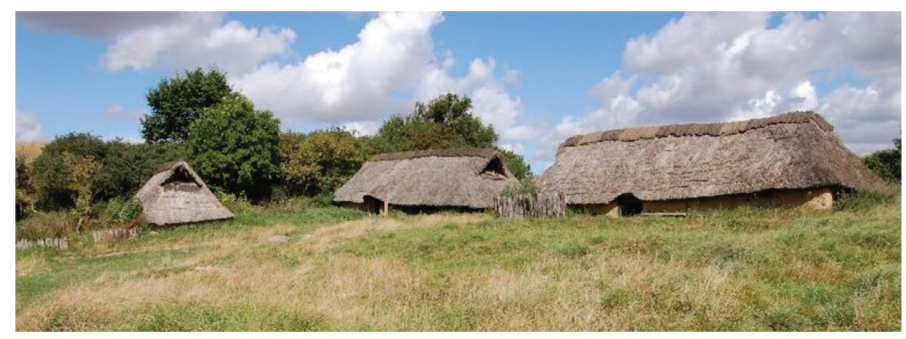

Figure 1: Reconstructions of Iron Age longhouses in Lejre. Photo by Michael Lauring. 


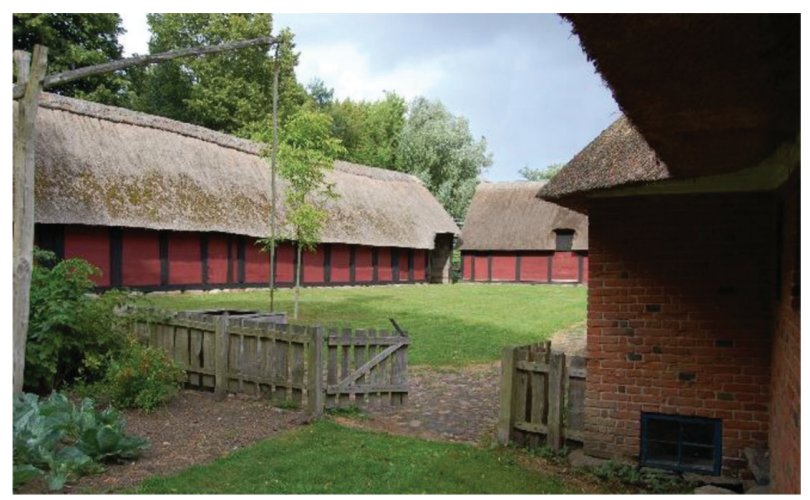

Figure 2: Winged farm from Barsø. Photo by Michael Lauring.

Urban residences for the non-wealthy population between the Middle Ages and Industrialization consisted of row houses that would contain both family and shop or workshop in one. Behind the house, a small yard would provide space for vegetable and animal produce. The orientation of these houses would depend on the street pattern rather than the sun and wind. Later, these houses expanded vertically to form the common Danish city blocks [2-5].

\subsection{The connection with natural elements}

Early Danish architecture connected with the landscape through necessity, as a defense from the elements and as a provider of shelter for the inhabitants.

The generational knowledge gathered in vernacular architecture, which created buildings that were uniquely suited to the landscape and climate. The architecture would change over generations and slowly respond to climate and landscape, as they changed as well. Many of these buildings would consume large amounts of wood to heat sufficiently, which accelerated the deforestation of the landscape $[7,8]$.

\section{THE DETACHED HOUSE DEVELOPS}

In the late 19th century, industrialization brought railroads and urbanization. Both were influential in the development of the Danish residence. Industrialization arrived comparatively late in Denmark and was primarily linked to improvements in agriculture and food production.

In this period, small towns at railway stations grew quickly due to increased commercial activities and without any central planning. Nine out of 10 houses were built without an architect and were for the most part drawn, built and sold by local craftsmen. Many of the station and market towns therefore became eclectic mixes of what were considered fashionable styles at the time, inspired by other European countries. Many architectural movements came and went in the period, leaving marks on the developing national style [9].

At this time, the residential architecture had to move away from half-timbered constructions towards pure masonry, primarily using red bricks, which has since become synonymous with traditional Danish architecture.

The quality of housing improved for most members of society around 1900, and the garden city movement originating with Ebenezer Howard started to become influential in Danish society. The period led to an increased understanding of both climate and landscape in relation to dwellings. 
As a reaction to the eclecticism of the time, the 'Skønvirke' movement, consisting mostly of young architects, attempted through studies of vernacular national architecture to create a semblance of unity in the architecture of the new cities. This was exemplified in a full-scale model of an ideal station city, which was shown at the national exhibition in Aarhus in 1909. The exhibition was a call for a national style and became a precursor for the prominent 'Bedre Byggeskik' (better building practice) movement, which was founded in 1915.

Bedre Byggeskik developed a simple model for detached single-unit housing. It was designed by architects, with drawings and advice to builders, with the purpose of improving the quality of Danish housing. The result was a simple and compact red brick detached housing type that suited the climate and landscape. The success of the style is still evident in Denmark, with many of the houses still in use. The houses had a useable plan designed around the central fireplace, which distributed heat, and were a product of the local climate. The organization also educated craftsmen in the art of house-building and raised the standard of residential architecture to an impressive degree during the organization's lifetime $[9,10]$.

\subsection{Connection with natural elements}

The Early Industrialization period saw rapid changes in architecture, with international inspiration countered by regional responses. The eclectic developments in the new station cities provided inspiration that had been foreign to the Danish landscape.

Skønvirke sought a new style in the vernacular, to create a suitable contemporary architecture for the Danish climate and landscape.

Bedre Byggeskik developed a Danish architecture where climate, form, orientation and plan worked in unison. The houses were well suited to climate and the Danish landscape but did not engage in a meaningful way with nature beyond that.

\section{MODERNISM AND THE DANISH FUNCTIONAL TRADITION}

Modernism in the early 20th century heralded an international style, where technology and construction methods would allow architecture to shed its cultural baggage and extend across borders. Modernism called for a new approach to climate and landscape. International architecture was to use technology to create a building separated from natural forces of nature, but visually engaged with the landscape through large glass facades.

White concrete and large glass facades became central elements in the abstract architectural language of the period. The style designed for a Mediterranean climate was ill fitted for the wet Danish weather. The international style had moderate success in Danish residential architecture from the late 1920s to the mid-1930s, but most Danish architecture remained brickwork (Fig. 3).

However, the white modernistic style was transformed into 'funkis' and later into what Kay Fisker described as 'the Danish functional tradition' that largely accepted the landscape and climate as integral in architecture. An element of this approach was the integration of garden and architecture, where transition elements would facilitate a blending of spaces. The bungalow, which had its origins in India, with its raised terrace that allowed inhabitants free access to sun and fresh air introduced such threshold spaces. Later developments saw a romantic approach to the garden as a natural refuge from the industrial workday, for instance, in G.N. Brandt's designs, while others like C. Th. Sørensen approached the garden as a functional space like any other room in the residential architecture [10,11].

There was a strong focus on Nordic light as an architectural element; light became a source of well-being contrary to the insulating but enclosed architecture of old. This is of course 


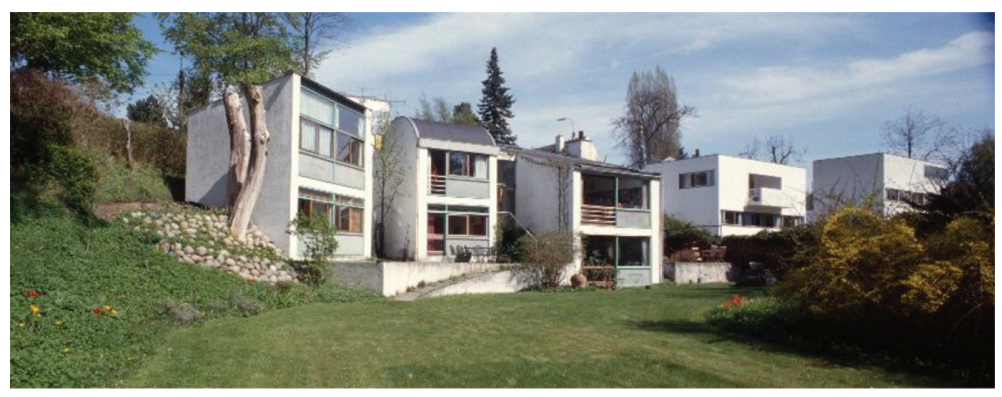

Figure 3: Sølystvej 9-11 Danish functional tradition houses by Mogens Lassen (1938), in the background Sølystvej 5-7 in international style. Photo by Per Munkgaard Thorsen.

long before the concept of sustainable architecture, but the sensitivity of architecture was developing in the period. The houses featured plan layouts that utilized sun and air as central elements. Examples of the architecture from the period show understanding of the Danish climate and landscape $[10,12]$.

\subsection{Connection with natural factors}

The connection to, or the acknowledgement of, nature changed radically in this period. The International style, while generally not breaking through into the design of Danish detached housing, did have a lasting impact on the apartment blocks that would become a stable element in the Danish housing architecture in the following decades.

The Danish functional tradition was less radical and there are plenty of examples where the architecture in the Danish functional tradition joins the building and landscape. In the 1940s and 1950s, a particular sensitivity to nature developed, which is unlike most other Danish architectural style periods.

There is also a sensitive architectural interplay between materials and landscape. The interplay was mostly aesthetic, but the best examples used landscape and microclimate functionally. Many of the designs blended with the landscape in a way that shelters the house while avoiding runoff water and moisture, as would be expected in the Danish building tradition. The design for indoor climate and energy demand is rudimentary, the houses can therefore be somewhat exposed to extreme heat and cold, and sensitivity to the contours of the landscape makes the houses better fitted for hydrological phenomena [10-11].

\section{EXPANSION}

In the 1960s and 1970s, the Danish residential stock expanded extraordinarily, partly due to the large war generations reaching adulthood and partly due to a booming economy.

\subsection{Type of houses}

For the housing market to follow this growth, new industrial prefabrication methods were invented in the building industry. The architecture of these houses was conservative and with economic concern as the main design driver. The rapid expansions of the suburbs created residential districts that absorbed local green fields at a voracious pace [10].

The expansion of the housing stock in the 1960s and 1970s answered a demographical problem but ended up creating new ones. Planners fielded a rational approach to the design 
of new neighborhoods, and the plots were distributed in a rigid grid system that swallowed the landscape surrounding the cities. The neighborhood structures were designed in the local planning departments, rather than naturally evolving.

Most houses were hastily built and of a poor standard. The connection with the landscape suffered major setbacks in this period, in part due to the planning practices that became commonplace. The new buildings did strive for a level-free access to the gardens, compared to the raised level of the 'funkis' bungalows. This approach ignored the climatic and landscape conditions of Denmark. The floor construction was vulnerable to moisture, and the access directly to a levelled lawn made houses vulnerable to flooding and moisture damage from the ground.

The traditional building techniques that had created solid houses for most of the century were exchanged for methods that allowed structures to be assembled on factory floors. Many of the problems that the Danish housing stock struggles with nowadays are results of this period's hasty construction and cost-cutting measures. Combined with new building methods that the craftsmen had yet to perfect, housing of this time has gained a somewhat bad reputation [10].

Unlike the mass-produced houses, the gardens were still free for inhabitants to develop as they chose. Nevertheless, with both partners having jobs, the family gardens became deprioritized and lost their utilization as a source of produce $[10,13]$.

\subsection{Connection with natural factors}

The standard-plan house and massive suburban developments eroded the connection with nature that the 'Danish functional tradition' had created. Mass-produced housing was by definition not designed for the regional climate. New types of constructions saved construction time and helped energy savings, but the architecture became less robust. The architecture of the period has seen massive renovations over the years to adapt it to the Danish climate.

Gardens became outdoor spaces that provided a recreational space for the inhabitants but mostly lacked any use beyond that and became as monotonous as the standard house to which they were attached.

\section{ECOLOGICAL ARCHITECTURE}

In 1973, the oil crisis hit Denmark hard due to political tensions between the Danish government and the Middle East, which required major restructurings of society. Denmark was, at this point, completely reliant on imported oil for energy.

In residential architecture, a new mindset of energy awareness was enforced by strict regulations. At first, the regulations required smaller openings in the building facades to mitigate heat loss through windows and other low insulating elements. This resulted in a closed expression, where the visual connections to the exterior were limited when compared to previous decades.

There are early Danish examples of attempts at zero energy architecture at this point. The zero energy house at DTU was an experimental attempt that utilized passive solar energy to great effect [10].

The move towards a low-energy architecture went hand in hand with an awakened social indignation among younger architects, and a new socio-ecological architecture aiming for community and social interaction in dense/low settlements became the result. Tinggården by Vandkunsten is a prime example of this architecture, which also draws on the vernacular architecture for both plan layout and expression (Fig. 5). 


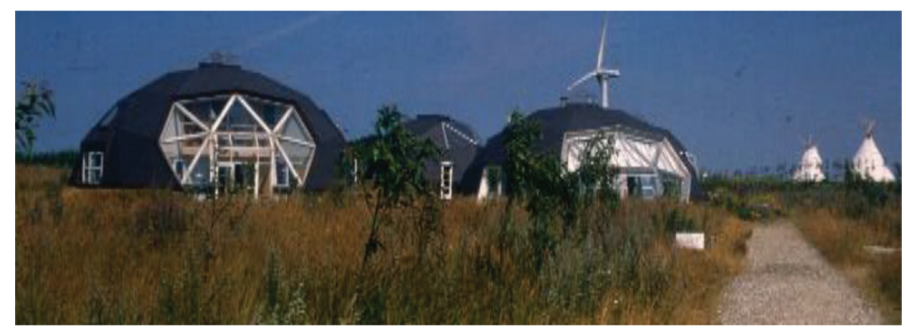

Figure 4: Ecological houses in Dyssekilde: Photo by Michael Lauring.

The ecological architecture had an experimentalism and an ideological drive leading to expressions that yearned to show the connection with nature and the technical innovations of the architecture.

The designs changed over time as the legal requirements shifted but overall, they show awareness of climatic conditions in the design, incorporating design elements from outside Danish tradition to maximize the intake of passive solar energy.

Notable examples in the ecological village Dyssekilde show how natural factors radically influenced form-finding in the design (Fig. 4). Many of these designs were ideologically founded or sought inspiration in foreign designs that did not translate into the Danish climate, in many cases the buildings being worse energy consumers than standard houses due to poor indoor environment $[14,15]$.

Ecological architecture depended in many ways on international inspiration. Derived from necessity due to the oil crisis, many of the buildings developed through using designs from foreign climates. As the building code developed, so did the architecture. The early designs included winter gardens acting as solar conservatories. This was a method to get around the maximum window area limitations in the building code. In 1995, these strict limitations were supplanted with an energy frame allowing the designer to engage a number of parameters.

Other strategies involved using solar conservatories for thermal regulation over the seasons. This had proved to be effective on paper and in other climates, but had negative side effects in Denmark, where transitional spaces were still uncommon. The spaces ended up being used as living rooms, thereby negating any positive effect of the design [14].

\subsection{Connection with the natural factors}

Ecological architecture attempts to gain benefits through climatic design and social sustainability. Some examples of the ecological buildings were more overt in their integration

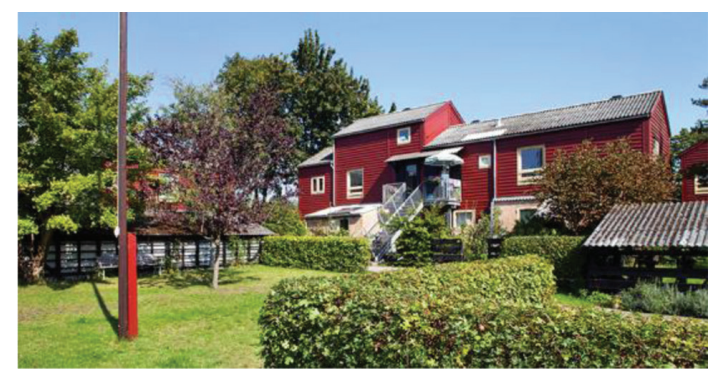

Figure 5: Tinggården by Vandkunsten. Photo by Michael Lauring. 
with the landscape, but still come across as an aesthetic manifestation of an ideal environmentalism [16].

Most ecological design was focused on an 'inward' sustainability where the building could maintain low energy demand and social integration without engaging the exterior landscape. Integration with natural features and ecology were lacking; sustainability was rather sought through technology or conservation of materials. Some notable exceptions were the works of Vandkunsten who at this point worked intimately with the building's physical interaction with the landscape [16].

\section{SUSTAINABILITY AND BEYOND}

Pushed by regulations, environmentally sustainable architecture has become the new norm in Danish architecture. While most of the low-rise residential building stock consists of the detached typeset houses of the 1960s and 1970s, these might face energy retrofits or demolition.

\subsection{The sustainable residence}

As regulations tightened and technology developed, low-rise residential architecture has developed and surpassed ecological architecture in environmental sustainability.

The architecture has developed into pragmatic and minimalist aesthetics where, contrary to ecological architecture, very little is mitigated by sustainability.

All new houses in Denmark must uphold rigorous standards on energy usage, mostly focused on minimizing heating demand. This standard has been phased in over the last decades and accelerating since 2006. The upcoming 2020 Building Regulations require maximum $20 \mathrm{~kW} \mathrm{~h}$ per $\mathrm{m}^{2}$ energy use, including heating, cooling and hot water [17].

Most of the new residential houses in Denmark are mass-produced concrete architecture with some sustainable buildings using wooden constructions. The aesthetic expressions of the house are often simple geometries with stout details because of the heavily insulated envelope. Masonry is seldom used as supporting structure but remains as external cladding of concrete structures.

The architecture will, in most cases, account for sun and wind in the design, although there is a tendency for the microclimatic consideration to be somewhat simplified. Several newer plans for sustainable housing tend to use multiples of the same buildings with differentiated orientation, which makes the effects of sun and wind less predictable. This implies that these developer-driven sustainable buildings often lack any kind of connection with the landscape or any actual understanding of the climate or of climate change. In Denmark, the discourse on climate change with regard to the building stock is centered on precipitation and flooding, which is the most immediate economic threat to the building stock $[18,19]$.

There are major public investments in flood protection in most Danish cities, but these are focused on the protection of the urban fabric, for a large part disregarding the potential role of architecture and active adaptations to climate change. From 2018, new developments in Denmark must take potential flooding and erosion into account $[3,20]$.

\subsection{Connection with natural factors}

For residential architecture to adapt to climate change, it ought to be designed taking climatic conditions and landscape features into account. The gains from passive solar energy and 
wind-driven ventilation strategies are essential toward reaching the demands placed on sustainable buildings. However, these demands are in most cases static in nature and use older statistics to prove the environmental viability of the designs.

Sustainable houses in Danish architecture often show an affinity to solar orientation in the design. The architectural form is conceived to maximize the energy potential of PV systems. Often the problems of the passive, solar-designed ecological architecture are repeated, and the houses can suffer from overheating in the current climate $[14,18]$.

Some sustainable developments attempt to counteract flooding, with rain gardens and similar measures; these will be required to have level-free access, which might cause problems with flooding, as a clear separation between the buildings and the adaptive measures in the urban space, rather than a cooperation of architecture and landscape.

Danish housing architecture has become more international during the last decades. With more studios working on international assignments, the understanding of the Danish landscape and climate has been somewhat lost in the praxis.

\section{DISCUSSION}

When researching the development of Danish low-rise residential architecture and the connection with the natural factors of landscape, climate and ecology, it is evident that while technological prowess has improved markedly, there has been a loss in sensitivity to nonhuman factors of natural context.

There seems to be a pattern in the development of residential architecture, where international inspirations are 'imported' to Denmark wholesale and are later moderated into a Danish architectural tradition. The moderation eases the architectural movements into landscape and climate, mitigating features that do not perform in the climate and reforming the style towards the Danish functional tradition.

Vernacular architecture was a function of the climate, landscape and communal/generational memory. It evolved organically over millennia along with the climate. The vernacular is the result of natural factors as a means of survival in a resource-scarce society.

Twentieth-century urbanization and the international style led to a more sustainable way of living. The densification and improved building standards alleviated the diseases and misery that had been common in the previous centuries.

The Danish functional tradition has been influential; it defined a regional modernism that are the Danish landscape and climate. The garden became an extension of the architecture, both aesthetically and functionally providing health and recreation for the inhabitants.

The later development of the standard-type house and the mass expansion of the suburbs appear as the low point of the connection with nature. However, the large gardens would provide diversity. The gardens were generally larger than current houses, and the houses were likewise smaller than those today.

Ecological architecture is an interesting development in regard to mass housing, which in many ways achieves a higher degree of both environmental and social sustainability, without much natural sensitivity.

Current architecture in Denmark is focused on low energy consumption, which relies on thick layers of insulation and mechanical conditioning. The houses produced by the paradigm are naturally cut off from the exterior. Unfortunately, the resilience of the systems can be low and produces problems with indoor climate and in the end a worse energy performance and loss of greenhouse gas mitigation, should climate change become severe. Accessibility requirements might also lower flood resilience and make adaptations even harder to implement $[14,15,21]$. 
In Denmark, the current building codes stipulate strict requirements for energy use and indoor climate, but all documentation thereof is made with climatic calculations of previous decades and with no requirements to calculate climate changes, although new plans stipulate consultation of flood-risk maps, as part of the process $[3,17]$. Therefore, many new Danish houses are not designed for the current climatic environment and will perform progressively worse in even the most optimistic expectations of climate change.

\section{CONCLUSION}

The development of Danish residential architecture has flowed from international impulses to Danish adaptation to the landscape and climate. Currently, Danish architecture is experiencing such an international impulse. Regulations ensure that energy consumption decreases, but the building designs are often unfit for the climate and landscapes they will inhabit.

The immediate problems with flooding and coastal erosion can be resolved through intelligent building patterns, which are in some cases already being implemented in the Danish building codes [3]. There might be a need for further understanding how architecture interacts with, and is interacted upon by, the surrounding landscape, including how it responds to temperature changes, drought and air humidity, if climate change adaptation is to be achieved.

Gardens need to become more of a provider of resilience and adaptation, a water retention measure as well as a source of passive cooling. Plants can absorb and change the humidity of the ground to retain large precipitation events. Deciduous trees provide shading in the summer, but allow for passive heating in the winter, evapotranspiration will likewise maintain cooler air around the leaves, which can lower overall temperature. Gardens should act as an ecological buffer in the residential architecture, while the design of houses should be adapted to existing and future climates. Architects could likewise ensure that biodiversity is retained through the design of outdoor areas in especially suburban housing [22].

The current internationalization of Danish architecture will have to give way to a sensitive regional approach. The natural landscape must play a dominant role in urban planning. The architecture of house and garden will have to work in synergy to make itself and the surroundings resilient. Through intelligent planning, new detached settlements could raise the resilience of neighborhoods as a whole and meet the future challenges head on.

\section{REFERENCES}

[1] IPCC, Climate Change 2014: Synthesis Report. Contribution of Working Groups I, II and III to the Fifth Assessment Report of the Intergovernmental Panel on Climate Change. Geneva, Switzerland: IPCC, 2014.

[2] Kottek, M., Grieser, J., Beck, C., Rudolf, B. \& Rubel, F., World map of the KöppenGeiger climate classification updated. Meteorol. Zeitschrift, 15(3), 259-63, 2006. https://doi.org/10.1127/0941-2948/2006/0130

[3] Erhvervsstyrelsen, Vejledning i planlaegning for forebyggelse af oversvømmelse og erosion, Copenhagen, 2018.

[4] Jensen, J., Posselt, G., Truels-Kort. \& Steen Frimodt., Danmarks oldtid: fra stenalder til vikingetid, Gyldendal, 2013.

[5] Brogaard, P., Lund, H. \& Nørregård-Nielsen, H.E., Landbrugets huse. Gyldendal, 1980.

[6] Kjærgaard, T., Den danske revolution 1500-1800 : en økohistorisk tolkning. Gyldendal, 1996.

[7] Lauring, M., Bolig og Bebyggelse i Baredygtigt Perspektiv, 1st ed. Aarhus: Arkitektskolen i Aarhus, 1998. 
[8] Ørum-Nielsen, J., Langebolilgen, 1st ed. Viborg: Kunstakademiets Forlag, Arkitektskolen and Arkitektens Forlag, 1988.

[9] Balslev Jørgensen, L., Danmarks Arkitektur: Enfamiliehuset, 2nd ed. Copenhagen: Gyldendalske Boghandel, Nordisk Forlag A/S, 1979.

[10] Lind, O., Møller, J. \& Dirckinck-Holmfeld, K., Bag Hakken: Det danske parcelhus $i$ lyst og $n \varnothing d, 1$ st ed. Skive: Arkitektens Forlag, 1996.

[11] Millech, K., Danske Arkitekturstrømninger 18501950: En Artkitekturhistorisk unders $\phi$ gelse, 1st ed. København: Østifternes Kreditforening, 1951.

[12] Sestoft, J. \& Hegner Christiansen, J., Guide til dansk arkitektur 10001960, 1st ed. Skive: Arkitektens Forlag, 1991.

[13] Sjöman, J.D. \& Gill, S.E., Residential runoff - The role of spatial density and surface cover, with a case study in the Höjeå river catchment, southern Sweden. Urban For. Urban Green, 13(2), 304-314, 2014. https://doi.org/10.1016/j.ufug.2013.10.007

[14] Marsh, R., On the modern history of passive solar architecture: exploring the paradox of Nordic environmental design. The Journal of Architecture, 22(2), 225, February 2017. https://doi.org/10.1080/13602365.2017.1298652

[15] Marsh, R. \& Lauring, M., Architecture and energy: questioning regulative and architectural paradigms for Danish low-energy housing. Architectural Research Quarterly, 15(2), 165-75, June 2011. https://doi.org/10.1017/s1359135511000583

[16] Lauring, M., From ecological houses to sustainable cities. Architectural minds. Nord. J. Archit. Res., 22(1/2), 14, 2010.

[17] Bygningsreglementet, Bygningsreglementet 01.01.2017. vol. 2017, no. 01 May 2017.

[18] Hansen, E.K., Olesen, G.G.H. \& Mullins, M., Home smart home: a Danish energy-positive home designed with daylight. Proc. IEEE, 101(11), 2436-49, 2013. https://doi.org/10.1109/jproc.2013.2267622

[19] Brunsgaard, C., Heiselberg, P., Knudstrup, M.A. \& Larsen, T.S., Evaluation of the indoor environment of comfort houses: qualitative and quantitative approaches. Indoor Built Environ., 21(3), 432-51, 2011. https://doi.org/10.1177/1420326x11431739

[20] City of Copenhagen, Climate change adaption and investment statement part 1. 2015.

[21] Brunsgaard, C., Knudstrup, M.A. \& Heiselberg, P., Occupant experience of everyday life in some of the first passive houses in Denmark. Housing, Theory and Society, 29(3), 223-54, 2012. https://doi.org/10.1080/14036096.2011.602718

[22] Hunter, M., Emerging landscapes: Using ecological theory to guide urban planting design: an adaptation strategy for climate change. Landscape Journal Design Planning Manage, 30(2), 173-93, 2011. https://doi.org/10.3368/lj.30.2.173 